\title{
JUURNAL.RU
}

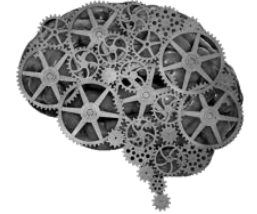

COMPANY GROUP "INTELLEKT"

Кириченко Н.С.

Управление Северо - Кавказского регионального командования внутренних войск МВД

России

Ростов-на-Дону, Россия

doi: 10.18411/lj2016-7-2-07

idsp 000001: 1j2016-16-2-07

\section{К вопросу об изменении понятия «административное расследование» в терминологии Российского военного права}

Любое определение должно быть ясным, четким, не допускающим двусмысленных или метафорических выражений. Это также относится к понятиям в юриспруденции.

Статья 7 Федерального закона Российской Федерации от 12 июля 1999 г. № 161 - Ф3 «О материальной ответственности военнослужащих» предусматривает обязанность командира (начальника) воинской части назначить административное расследование для установления причин ущерба, его размера и виновных лиц, в случаях его обнаружения. Аналогичные нормы содержатся в пункте 94 Устава внутренней службы Вооруженных Сил Российской Федерации. Понятие «административное расследование» также упоминается в части 6 статьи 28.6 Федерального закона Российской Федерации от 27 мая 1998 года № 76-Ф3 «О статусе военнослужащих». Также, многие нормативно правовые акты, регламентирующие вопросы деятельности органов военного управления, содержат понятие «административное расследование».

В соответствии с пунктом 13 Наставления по организации и осуществлению правового обеспечения внутренних войск МВД России при повседневной деятельности, а также при выполнении ими задач во внутренних 
вооруженных конфликтах немеждународного характера и особенностях применения в них норм международного гуманитарного права, утвержденного приказом главнокомандующего внутренними войсками МВД России от 5 июля 2005 г. № 220, под административным расследованием (разбирательством) понимается деятельность воинских должностных лиц по установлению фактических обстоятельств совершения военнослужащими, гражданским персоналом правонарушений, причинения ими материального ущерба, в целях принятия законного и обоснованного решения. В Федеральном законодательстве данное понятие не раскрывается.

Таким образом, в нормативно - правовых актах российских военных ведомств под «административным расследованием» понимается внутреннее служебное разбирательство, проводимое органом военного управления по какому - либо факту (событию).

В тоже время, понятие «административное расследование» содержится в статье 28.7 Кодекса об административных правонарушения Российской Федерации, которое заключается в проведении соответствующей процедуры административного расследования по факту совершения административных правонарушений. В данном случае, административное расследование это процедура, проводимая только уполномоченными на это государственными органами и только по факту совершения административного правонарушения.

Таким образом, одно понятие в соответствии с различными нормативными правовыми актами России имеет различное значение. Автор работы нередко сталкивался с ситуациями, когда судьям районных судов, не сталкивавшимся с нормативными правовыми актами РФ, регламентировавшими вопросы прохождения военной службы, но рассматривавшими такие споры, приходилось разъяснять, что в рассматриваемом споре под понятием «административное расследование» имелось ввиду именно служебное разбирательство, а не то, которое проводится в соответствии с Кодексом. 
А.В. Пчелинцев в 1987 году в своей диссертации кандидата юридических наук«Административное расследование в Советской Армии и Военно-Морском Флоте (организация и правовое регулирование)», писал, что под административным расследованием в Вооруженных Силах следует понимать часть административного процесса, представляющего собой деятельность командиров (начальников) и назначенных ими лиц по установлению фактических обстоятельств проступков военнослужащих, рабочих и служащих Вооруженных Сил, а также иных событий и фактов, которые нуждаются в выяснении в целях принятия на основе собранных доказательств законного и обоснованного решения. Термин «административное расследование» в настоящее время не соответствует сущности расследования служебных проступков и происшествий в порядке подчиненности. Более правильно такое расследование в Вооруженных Силах именовать служебным.

Мы полностью согласны с указанным мнением ученого.

C момента написания указанной диссертации прошло почти 70 лет и понятие «административное расследование» в Российском военном праве так и осталось без изменения, создавая двусмысленность и неоднозначность.

Мы считаем, что данное понятие необходимо исключить из терминологии Российского военного права и соответственно из нормативных актов Российской Федерации, регламентирующих вопросы прохождения военной службы, заменив понятием «разбирательство», которое уже присутствует в нормативных актах и имеет схожий смысл с соответствующим понятием «административное расследование». Кроме того, полагаем необходимым внести дополнения в Устав внутренней службы Вооруженных Сил Российской Федерации в виде исчерпывающего определения понятия «разбирательство». 


\section{Литература:}

1. Федеральный закон Российской Федерации от 27 мая 1998 года № 76-Ф3 «О статусе военнослужащих».

2. Федерального закона Российской Федерации от 12 июля 1999 г. № 161 Ф3 «О материальной ответственности военнослужащих».

3. Устав внутренней службы Вооруженных Сил Российской Федерации.

4. Наставление по организации и осуществлению правового обеспечения внутренних войск МВД России при повседневной деятельности, а также при выполнении ими задач во внутренних вооруженных конфликтах немеждуна-родного характера и особенностях применения в них норм международного гуманитарного права, утвержденное приказом главнокомандующего внутренними войсками МВД России от 5 июля 2005 г. № 220 .

5. Корякин Виктор Михайлович. Военное право: антология диссертаций. Часть 1. «За права военнослужащих». Москва 2011. 